\title{
錫塩, 苝物學的研究補遺
}

\author{
村 上 清 作 \\ (京都帝國大學醫學部䒚物學教窒 [荻牛数授])
}

(昭和十一年七月三日受付)

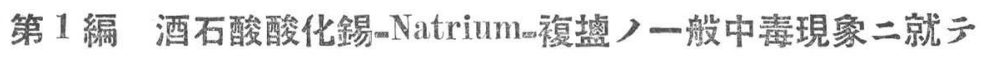

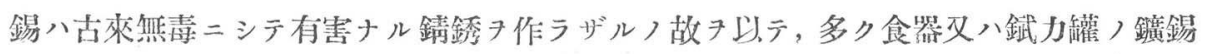
或八色装用锡䇠トシラ利用七ラレ, 其販路愈々擴大スル二作七, 市場二現ハレタル所謂, 商 業用錫ノ不絁トナリ1), 偶々現ハレタル罐詰中毒問題二關聯シテ, 錫中毒二關スル學者ノ注 意子渙起シ, 多數, 學者二依リテ毒物學的檢討 $1,2, n-7,16,18-22$ ) 7 蒙リタル結果, 之二關ス

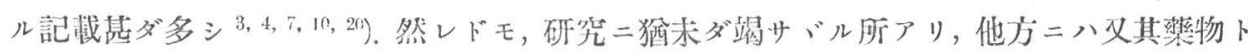

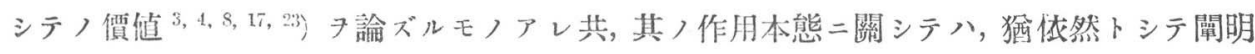
ナラズ.

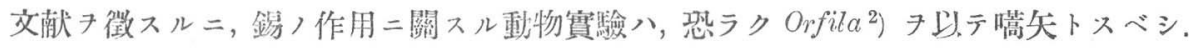
即于盐化第 1 錫 獨作用子硯フ二便ナラズ. White ${ }^{3}$ ) 八比較的二激烈ナル局所作用キ有スル醋酸-Triäthyl-錫 $\mathrm{Sn}\left(\mathrm{C}_{2} \mathrm{H}_{5}\right)_{3} \cdot \mathrm{C}_{2} \mathrm{H}_{3} \mathrm{O}_{2}$ 卜吸收容易二シテ作用緩和ナル 酒石酸酸化錫-Natrium 7 上テ, 錫)

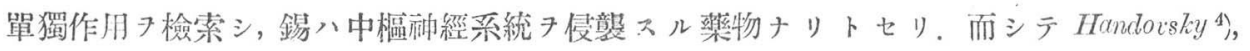
Schmiedeberg, Schübel 5) 及ビ其他多數) 學者モ亦之二賛同七り.而シテWhite)全實驗二共通 シタル事賽八, 適用後锡八直于二作月スル事ナク, 從ツテ其外觀的中毒症狀, 㗶現过二八,

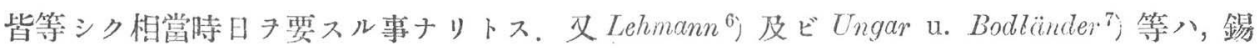

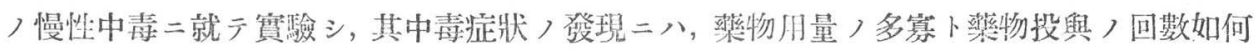

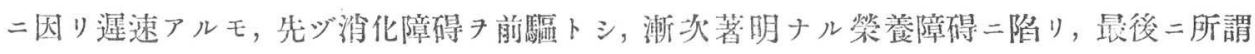
“Zinncachexie” 起シ, 終二 1 子年後二於テ漸ク重金屬二特有ナ几中毒症状子惹起シ, 爾

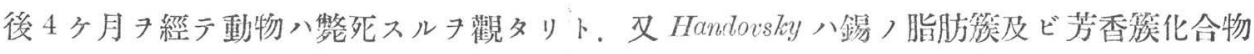

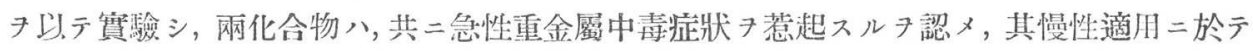
八, 芳香族化合物八脂肪㵀化合物ヨリモ毒力弱》, 且其急慢兩中毒間二於テ, 著シキ作用 ノ相堂アルタ認メ，更二爾化合物，慢性中毒中，皮下適用，場合二於テハ，脂肪族化合物

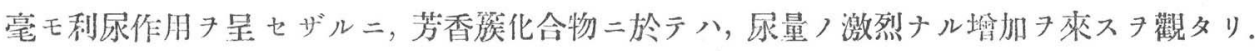
然レ其此際尿中蛋白丹認メザリシノそナラズ, 該利尿作用ノ頂嫼並二其鈍麻後二於テ剔出 


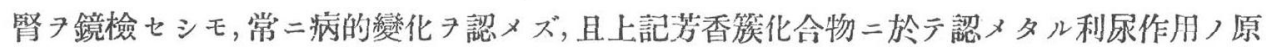

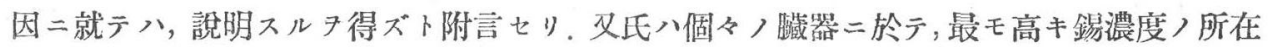
地八, 最大, 障碍丹蒙レル場所二非ズ. 從ツラ個々, 臓器二於々ル毒物, 分布八中毒症狀

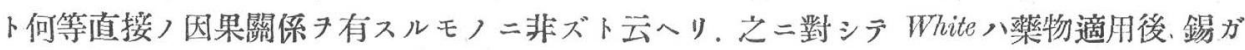
血液ヨリ組織内二全ク移行シ去ルニ八數日タ要シ, 從ツテ錫ノ作用ノ開始スル頃ニハ, 最早

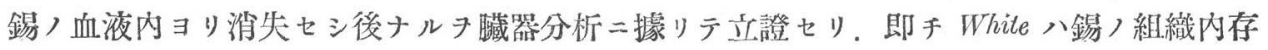

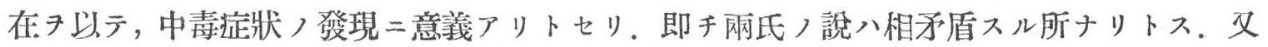
Louros u. Scheyer ${ }^{8}$ ) 二依レバ, 細胞內二領食七ラレタル金屬（錫》含ム）八, 網狀織內皮細 胞系統 フ純器械的二刺战スル外, 體液ニヨリテ惹起七ラレタル”Oligo-力性作用“二因リ， 一定ノ作用丹發現スルニモ亦想到スベキモノナリトシ，斯カル金屬トシテノ細胞内存在八, 全ク意義ナキモノニ韭ズト論結セリ，更二Heinrich Luding ${ }^{9}$ ) 八，一般二金屬 つ熄類 八網

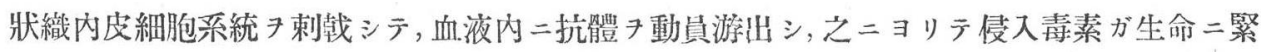
要ナル身體要素二有害ナル結合タナス以、前ニ之タ無害トナシ，又同時二抗體產生機轉，促 進作用习呈スルモノナルベシト。

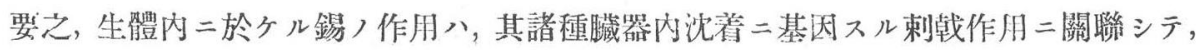
墫探究スベキモノ少カラザルモノアリト認ム。仍而, 余八腎炡. 特二網狀織内皮細胞系統二

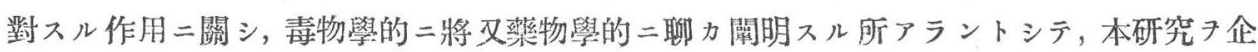
テタリ。

\section{實驗材料及ビ實驗方法}

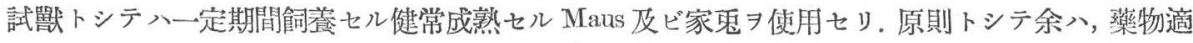
用後試獸ノ中毒㓠態 7 仔細二觀察シタル後, 之 7 失血死二陷シシメ, 或八中毒死後之 7 剖檢シ, 更二剔 出臟器二就キ, 切片標本 7 作製鏡檢七リ. 即千切片八 Hämatoxylin-Eosin 染色法 $\exists$, 又脂肪體染色二八 Sudan III. ヨ用ヒタリ.

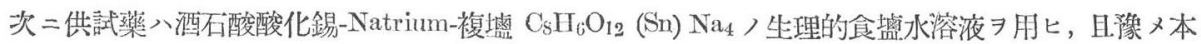

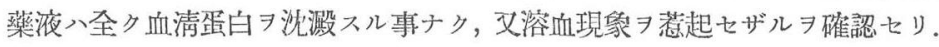

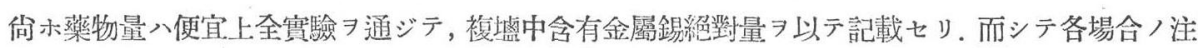
射液容量入, Mans 二於テハ對鳢重 $10 \mathrm{~g} 0,5 \mathrm{ccm}$, 又家鬼二八對體重 $1 \mathrm{~kg} 1 \mathrm{ccm}$ / 容量トナル樣, 適宜濃 度ノ溶液 $习$ 作り, 夫々皮下又八静胍內二注射七り。

\section{實 驗 成 績}

\section{Maus ニ就テノ實驗}

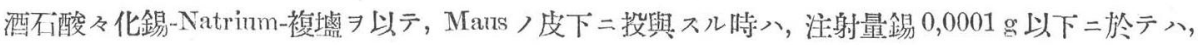

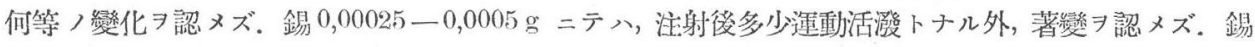

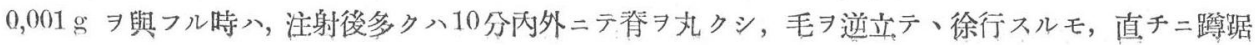


シテ呼吸促迫 / 狀 7 呈ス。然レ共 30 分後二八常態二復ス. 錫 $0,0025 \mathrm{~g}=$ ニ , 一般二注射直後八寧口

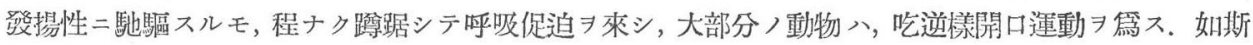

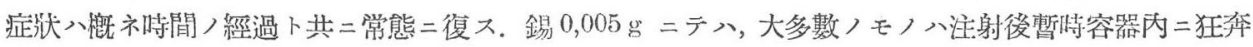

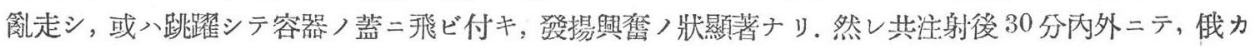

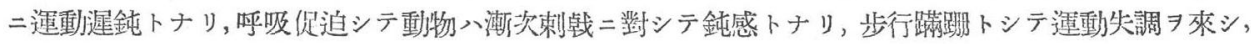

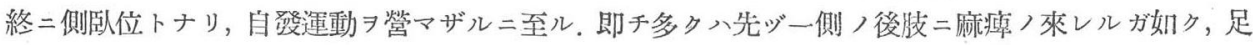

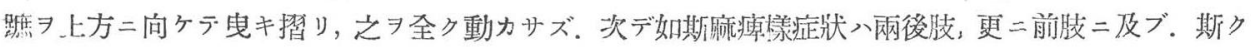

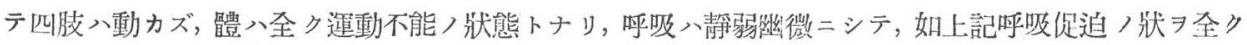
認ムル能ハズ。如斯狀態ヨ门再ビ恢復シテ多少自發運動入艮好トナルモ, 次デ復運動不能二陷儿。動物

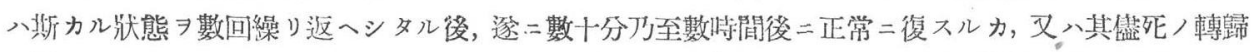

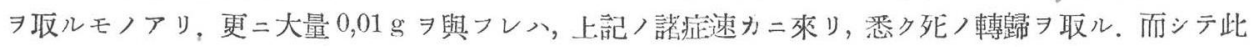

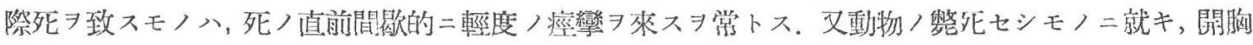

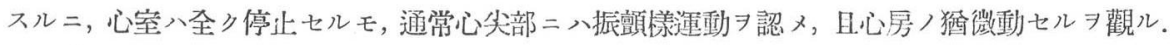

倘木酒石酸-Natrinm $\ni$ 以テセ儿對照實驗二於テハ, 錫 $0,005 \mathrm{~g}$ 以下二相當スル量二於テ，著變 7 認

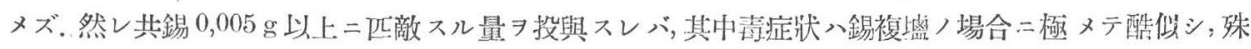

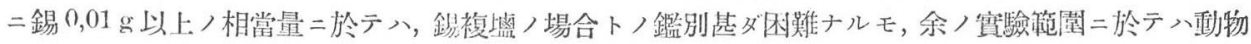

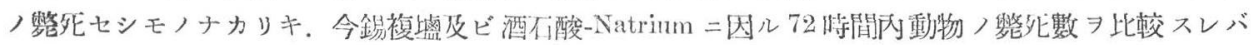
次, 如シ.

第 1 表. Mars 二就テ)實羷 坡下注射).

\begin{tabular}{|c|c|c|c|c|c|}
\hline \multirow{2}{*}{$\begin{array}{l}\text { 樂物投與量 } \\
(\mathrm{g} \text { pro } 10 \mathrm{~g})\end{array}$} & \multicolumn{3}{|c|}{ 藥 } & 名 & 稱 \\
\hline & 鍟 & 複 & 塯 & \multicolumn{2}{|c|}{$\begin{array}{l}\text { 酒石酸-Natrium } \\
\text { (對 照) }\end{array}$} \\
\hline 0,0001 & \multicolumn{3}{|c|}{$0 / 10$} & \multicolumn{2}{|r|}{$0 / 10$} \\
\hline 0,00025 & \multicolumn{3}{|c|}{$0 / 10$} & \multicolumn{2}{|r|}{$0 / 10$} \\
\hline 0,0005 & \multicolumn{3}{|c|}{$0 / 10$} & \multicolumn{2}{|r|}{$0 / 10$} \\
\hline 0,001 & \multicolumn{3}{|c|}{$0 / 10$} & \multicolumn{2}{|r|}{$0 / 10$} \\
\hline 0,0025 & \multicolumn{3}{|c|}{$1 / 10$} & \multicolumn{2}{|r|}{$0 / 10$} \\
\hline 0,005 & \multicolumn{3}{|c|}{$5 / 10$} & \multicolumn{2}{|r|}{$0 / 10$} \\
\hline 0,01 & \multicolumn{3}{|c|}{$10 / 10$} & & $0 / 10$ \\
\hline
\end{tabular}

注 意： 表中/分數式二於テ, 分母八使用動物數, 分子八其擎死數

要之, 酒石酸酸化錫-Natrium-複壏, Maus 二對スル作用八, 動物體重二比シ, 秒々大量

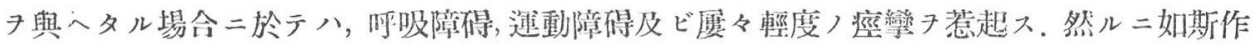
用八, 酒石酸-Natrium, 一定量ニヨリテモ惹起セラレ, 其症狀八彼此甚ダ相類似セリ。唯

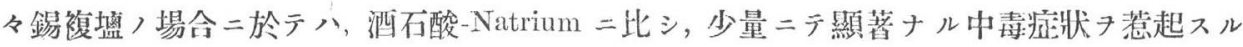
ト, 一定量以上ノ投與ノ場合二ハ, 酒石酸-Natriumニテハ, 全ク動物)整死キ來サバル二,

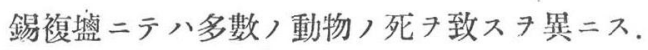

\section{2. 家鬼ニ就テノ實驗}

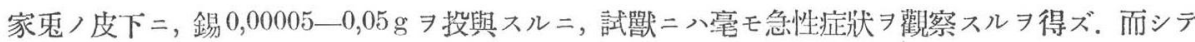


急性中毒症狀/出現著明ナルガ如キ過剩ナル藥物投與二於テハ, 含有酒不酸二因ル作用㙷著二現ハレ，

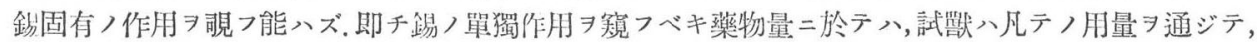
少クトモ数日間何等, 外觀的中毒症狀 モモ呈せズ. 故二余八稍々長期二互りテ其中毒經過 7 觀察七り. 即于本藥物) 比較的少量(錫 $0,0001-0,0025 \mathrm{~g}$ ) 7 皮下二注射スル二,全ク外觀的二何等) 中毒症狀 $コ モ$

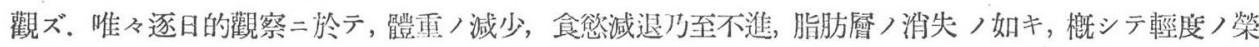
盖漳得及ビ時二尿中蛋白ノ出現 フ認ムルモ，間モナク恢復ス。次二其比較的大量 (錫 $0,005-0,05 \mathrm{~g})$ 週

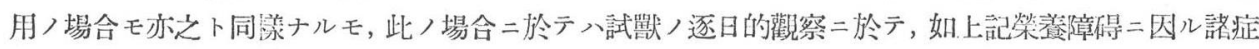

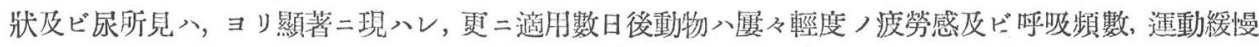

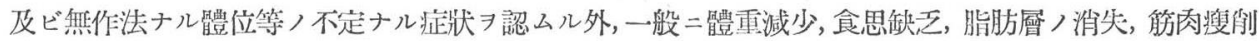

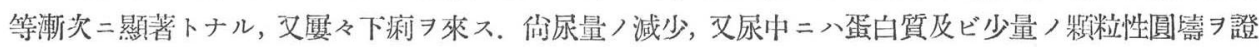
明シ, 稀二糖永习觀儿事アリ。

次二靜胍內適用二於テハ, 注射直後二於テ一過性呼吸促迫 7 認メタルモ, 忽千消失シ, 余 >用七タ 儿量的範園二於テハ,一般ニ特記スベキ作用习認メザリキ.

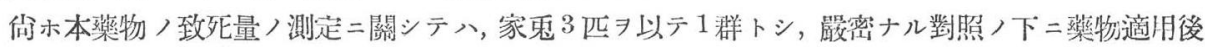

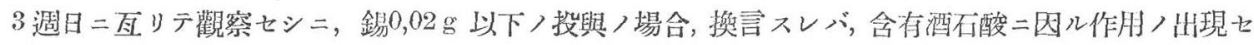

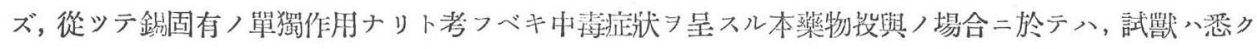

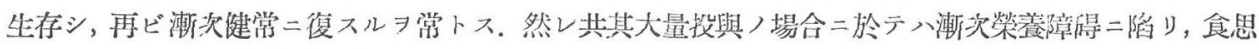

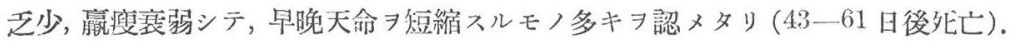

更二余八慢性䝵用二於テ，少量 $(0,00005-0,0005 \mathrm{~g})$ ) 錫 7 長期 $(6-8$ 迴間 $)$ 二互リテ連日注射

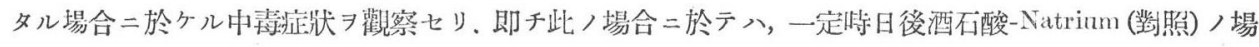

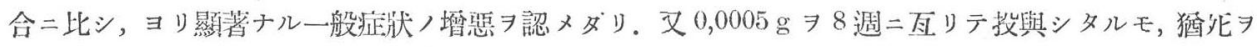
來ス事ナカリキ. 但シ此ノ場合二八, 一定洔日後尿中二蛋白/出現, 及ビ洔二病的沈椬习認ムルモ, 尿量

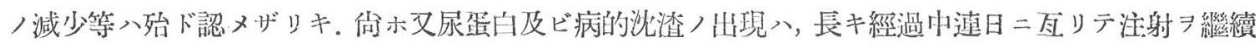

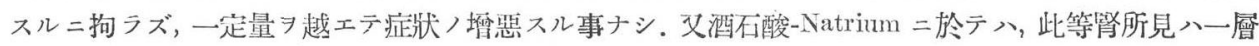
輕度ニシテ, 多クハ稀二蛋白尿习觀ルニ過ギザリキ.

次二余八上記家鬼, 賽驗中, 錫 $0,01 \mathrm{~g}$ 以上投與シタル動物, 及ど錫 $(0,0001 \mathrm{~g})$ )少量 7 数回二互り

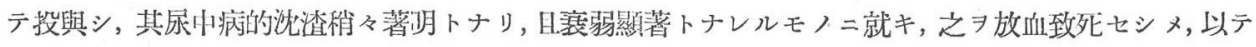

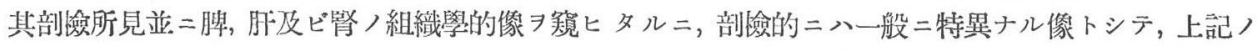

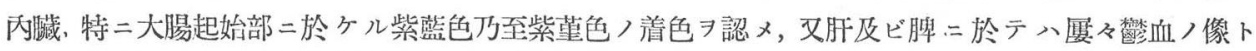

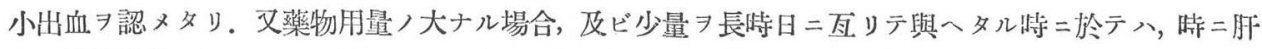

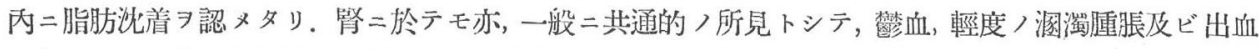

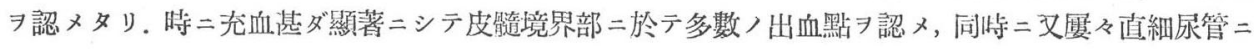
沿七, 乳頭二向七集束セラレタル赤色縱走線习認メタル事アリ. 消化管二於テ八, 大腸起始部二於ヶル

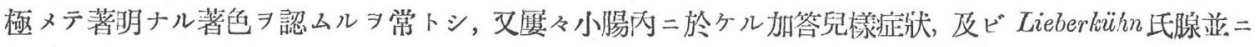
濾胞ノ肥大 7 認メタリ。

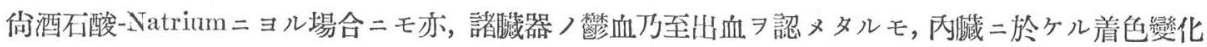
等, 一般二錫塭二比シ㙷著ナラズ.

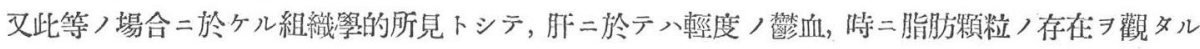
モ, 各例二於テ著明ナリシハ星芒細胞, 增殖及ビ肥大ナリトス. 倘如斯, 網狀織內皮細胞系統二於ヶル

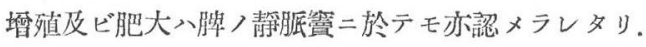

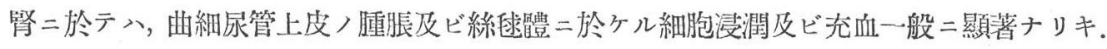

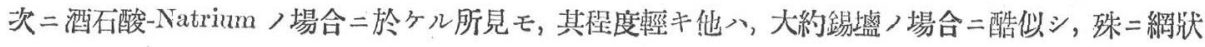


織內皮細胞系統八肥大增殖つ稍々著明ナリシハ, 特記ニ值スル事實ナリトス.

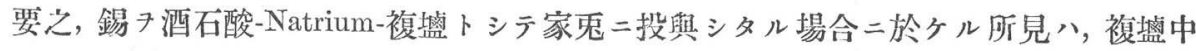
含有酒石酸-Natrium 量 (對照䔈噞) ニ於デ著明ナル作用ヨ呈セザル·量的範圍，用量二於テ 八錫特有ノ作用ナリト考フベキ急性中毒現象タ全ク認ムル能ハズ、唯々其慢性中毒經過， 觀察二於テ，一般二榮養障碍並二腎臟剌戟症狀卜見做スベキ作月ガ，錫複盢二於テ酒石酸一 Natrium 二比シ, 稍々著明ナリト認メタル二過ギズ. 你茲二特記スベキハ, 中毒試獸欌器, 組織學的所見二於テ, 酒石酸酸化-Natrium-殇複塭及ビ酒石酸-Natrium 八, 共二肝及ビ脾, 網狀織內皮細胞系統二對シ, 一定度ノ剌战作用

上記筫㬏成績丹觀ル二, 錫丹酒石酸酸化錫-Natrium-複盐トシテ動物二投與スル時ハ, 酒石酸-Natrium 夫レ自身が何等作用キ呈セザル用量ニテモ, Maus二於テハ, 唒呼吸障碍並 二運動障碍及ビ時二輕度ノ痘戀タ觀ルモ，酒石酸-Natrium卜ノ作用上ノ相違八，結局量的 關係ニ於テノて認メラレ, 複壒中含有錫量二匹敵スル量ヨリ稍々大ナル酒石酸-Natrium 量 ヨ投興シタル場合二於テハ, 兩者ハ頗ル相類似ス。唯々一定時間內二動物 死二致ス事, 複 盒ニ於テ顯著ナルモノアルチ認ム。

更二家鬼二於テモ亦, 上記，關係八同樣ナリ。即チ本藥物ニヨリ著明ナル急性症狀 觀ントスレバ，里竟之二匹敵スル酒石酸-Natriumニテモ亦, 殆ド全ク同樣ノ作用現ハス. 而シテ錫複盘二於テハ, White等ノ云ヘルガ如キ, 中樞神經系統二對スル錫作用八, 唯々 Maus 二於テノ $i$ 㥛メテ僅カ二認メラル、モ, 家鬼二於テハ不明ナリ. 由是觀ル二, White

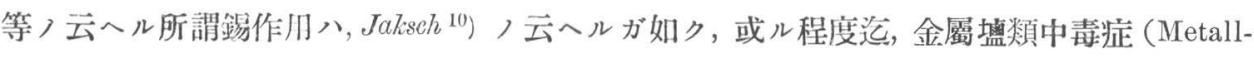
salztoxikose）ト混同スル所アルニ八非ルカ. 然レ共長時日二瓦ル慢性的觀祭二於テ，一定

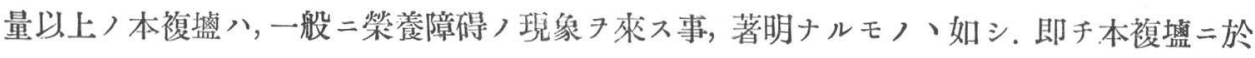
テハ，其量的二少キ投與，場合二於テ，對照タル酒石酸-Natrium ニテハ何等姃狀タ呈セザ

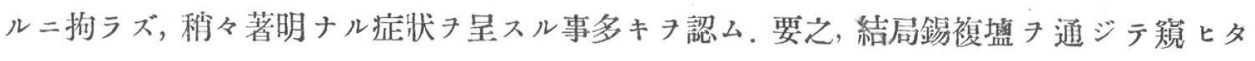
ル锡ノ作月夫レ自身ハ, 甚名顯著ナラザルモノト思惟七ラル、唯本賽驗中特記スべキハ,

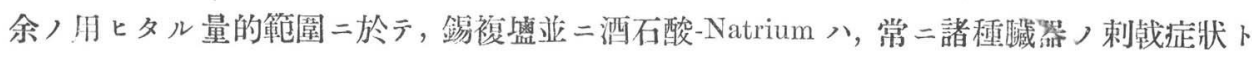
シテ, 臓器, 充血並二尿蛋白, 出現子來シ, 又中毒動物, 組織學的所見二於テ, 肝及ビ脾二

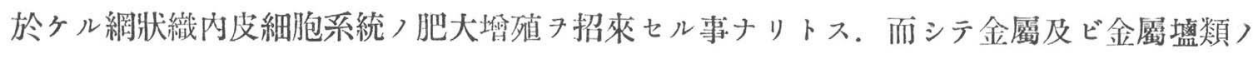
網狀織內皮細胞系統二對シテ, 刺戟促進作用 フ呈スルコトニ就テハ, Madsen u. Salomonsen ${ }^{\mathrm{I}}$ ), Wabbum, Louros u. Scheyer及ビLuding等) 報告アリ. 又Louros u. Schmeckel 15) 八連䥊狀球菌 傳染キ蒙リタル白鼠ガ, 酸性-及ビAlkali-性溶液, 投與ニヨリテ, 對照動物二比シ, $2-20$ 日 間生命延長的二作用シタルハ, 酸及ビ盐基ニヨリテモ亦, 網狀織內皮細胞系統ノ機能促進 セラレタル結果ナルチ, 組織學的二證明セシ事實二徵シ, 酒石酸-Natrium モ亦, 網狀織内 皮細胞系統ノ機能丹促進スル作用アル12,13,14) 丹認容シ得べシ. 


\section{第 2 編 酒石酸酸化錫-Natrium=䀄及ビ酒石酸-Natrium ） 葡萄狀球菌傳染二及状ス治療的慧義二關ス几㸴究}

金屬及ビ金屬櫒類，臨床的應用ハ，既二久シク行ハレ，其作用ガ局所作用上外二於テ

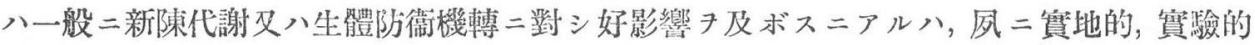
將又理論的二立證セラレタル死ナリ。

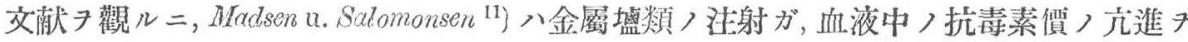

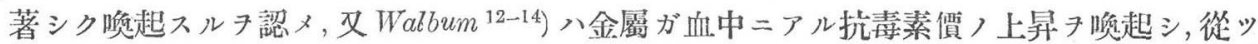

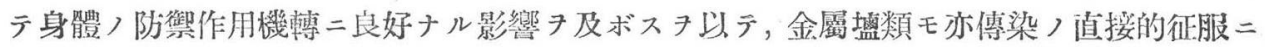

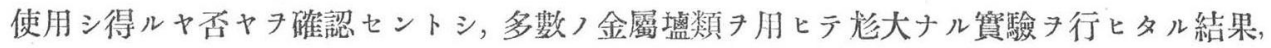
諸磒金屬盐類, 特二Mangan, Beryum, 这ビCaesium, 盐類ガ, 細菌傳染又心其毒素二因ル

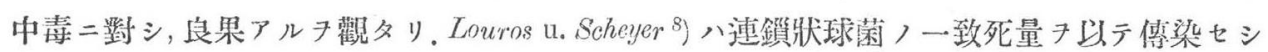

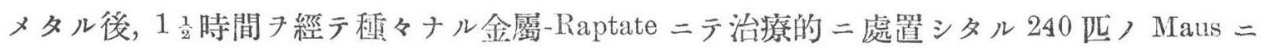
於テハ, 對照動物二比シ，3-20日間生命，延長セラル、フ觀，其效果八諾禈金屬中錫及ビ 金八最モ大二, 白金及ビ銀之二次ギ, Nickel，鉛及ビMangan そ二續キ，之二反シテ亞鉛， 水銀, 銅, 鐵, 蒼鉛及ビ砒素八對照動物二比シ, 連顉狀球菌傳染) 經過二八, 何等, 作用

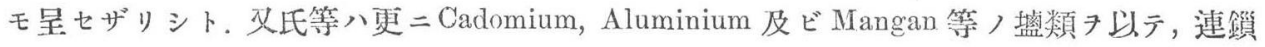

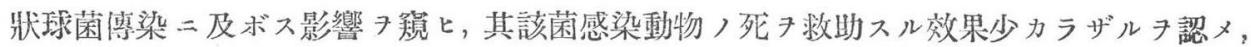

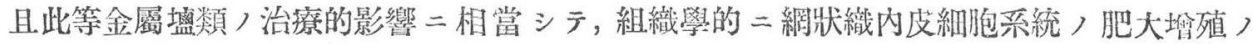
認メラル、事賽ヨリシテ，其治療的效果ハ，網狀織内皮細胞系統ノ機能九進二歸因スルモ ノナラント推論シ，金屬ハ獨り金屬-Kolloidノミナラズ，金屬盍類トシテモ亦，網狀織内 皮細胞系統ノ機能子促進シ, 以ラ傳染防衛上良好二作用スルモノナラント論結セリ. 又

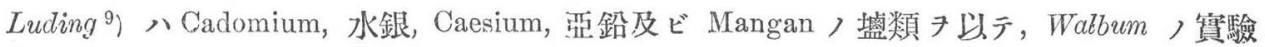

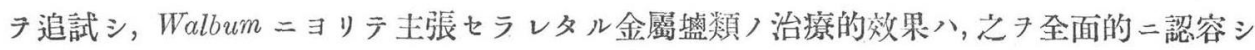

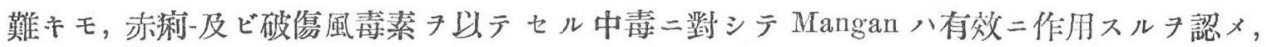
其作用二就テモ亦恐ラク網狀織内皮細胞系統ノ機能筧大二因ルモノナラントセリ.

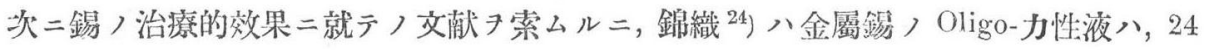

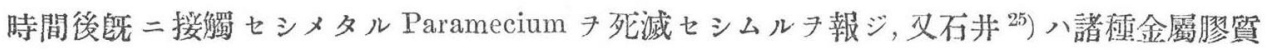
ノ細菌發育二及ボス影響タ觀察シ, 錫-Kolloid, 殺菌作用八各程桿菌及ビ孤菌亚二諸種㻖

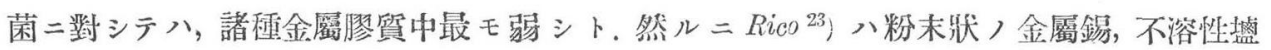
類タル酸化锡及ビ硫化錫, 並二其蛋白質中二化合セシメタルモノタ, 葡萄狀球菌) 培養基 二添加セシニ, 何レモ其發育阻止作用ハ極メテ不確賽ナリシタ報告七り. 而シテ錫粉未

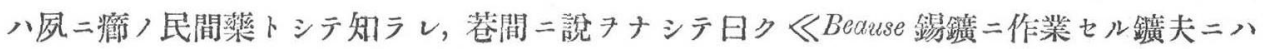


絕エテ揤二罹患スルモノナク，錫八實二葡萄狀球菌病二對スル特效藥ナり》! ${ }^{26}$ ). 又 Frouin

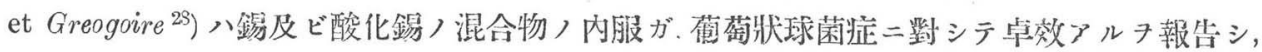

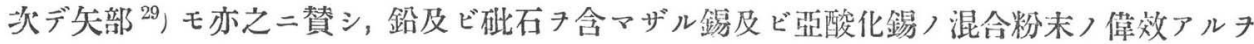

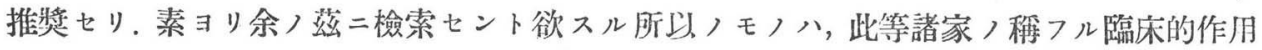

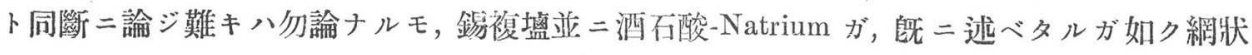

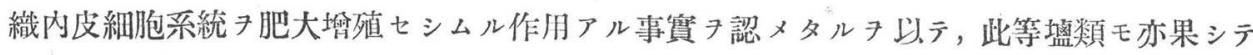

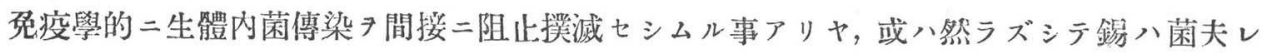

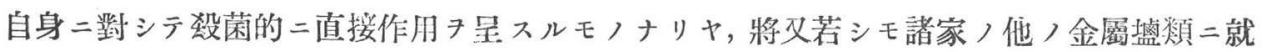
テ云へルガ如キ作用アリトセバ, 銆二就テ八其毒性ハ他ノ金屬二比シ著シク弱キガ故二, 酒石酸-Natrium-壏トシテ, 特殊的意義) 存スル事ナキヤ等々, 諸問題キ檢討セントシテ本 研究二從事セリ.

\section{實驗材料及ビ實驗方法}

供試苝立前篇卜同樣ナリ。

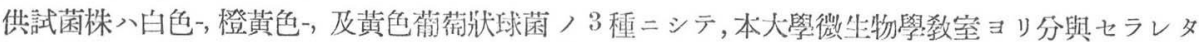

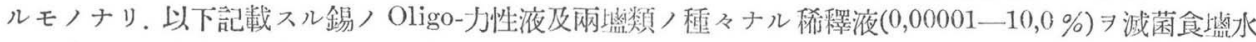
ニテ作り, 此等諸夜, $0,5 \mathrm{ccm}=, 10$ 倍二稀濢セル Bouillon $500,0 \mathrm{~cm}$ ）中= $1,0 \mathrm{mg}$ / 菌 含有スル菌 液习混ジテ, 種々ナル洔間 $\left(5^{\prime}, 30^{\prime}, 1 \mathrm{~h}, 3 \mathrm{~h}, 6 \mathrm{~h}, 8 \mathrm{~h}, 24 \mathrm{~h}, 48 \mathrm{~h}, 52^{\mathrm{h}}, 72^{\mathrm{h}}\right)$ 經過七ルモノ $7,57^{\circ} \mathrm{C}$ 二保テ

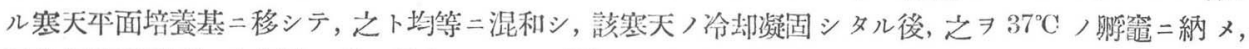

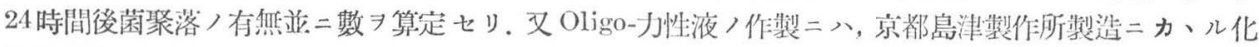

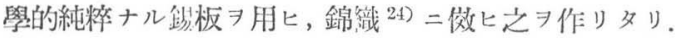

試獸入數日間一定)生活條件下二飼養七儿成熟 Maus 7 用七, 細菌八白色葡萄狀球菌—以下單二

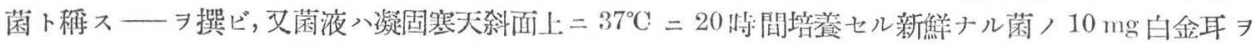

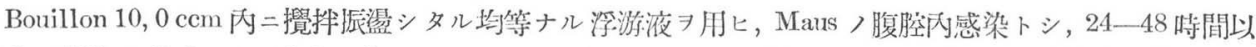

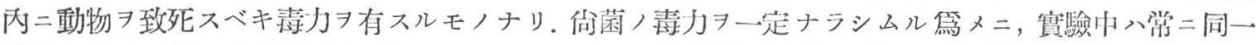
菌株, 保存二努メ, 又其容量入常 $=0,3 \mathrm{ccm}$ 卜, 以下注入液量 =因ル動物, 負据 7 可及的二輕減七シ

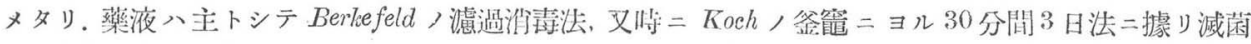
シ, 又藥夜容量八常 $=0,5 \mathrm{ccm} ト$ ト, 藥物ノ絕對量ヨ之二含有七シムル樣計算シ, 皮下二注射七リ。本實

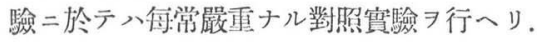

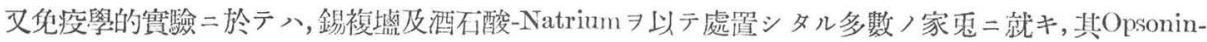

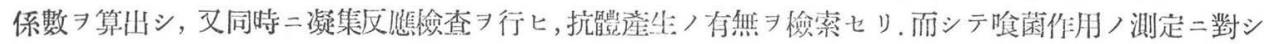

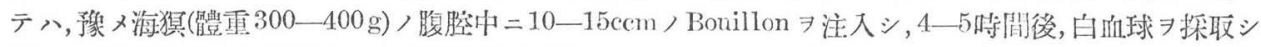

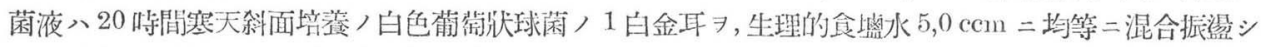

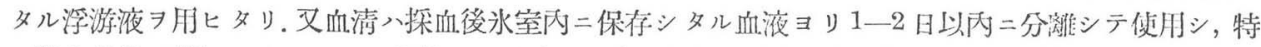

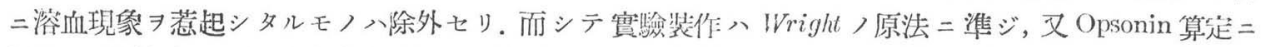

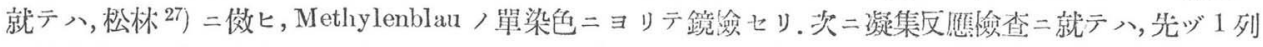

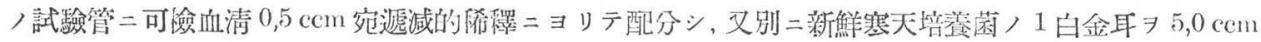

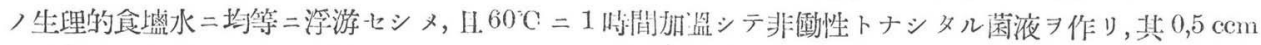

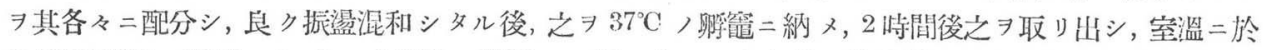

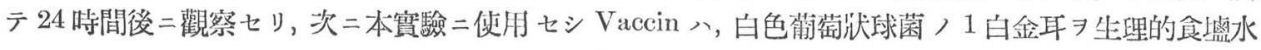


$5,0 \mathrm{ccm}$ / 割合二稀釋シ， $60^{\circ} \mathrm{C}=1$ 時間作用セシメテ非働性トナセルモノナリ，文燕液入皮下 八耳殼静胍內二注入シ, 藥物用量及 Vaccin-量八 $1 \mathrm{~kg}$ 二對スルモノトス.

\section{實 驗 成 績}

\section{I. 酒石酸酸化錫-Natrium-複埇及ビ酒石酸-Natrium 並ニ錫ノ Oligo-力性液ノ殺菌力試驗}

余八實驗方法二記載スルガ如キ方法 $フ$ 以テ, 此等藥物 73 種ノ球菌二作用セシメテ其發育二對スル

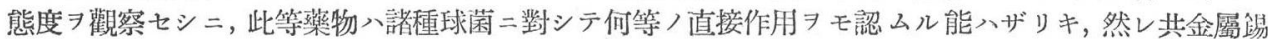
, Oligo-力性液 $\exists$ 作リ, 之卜上記, 菌夜卜均等二混和シテ一定洔間試驗管內二作用セシメタルモ, $57^{\circ} \mathrm{C}$ 二加溫七ル寒天培養基二投ジテ, 菌聚落, 發育狀態习觀察セシ二, 該 Oligo-力性液八菌二對スル直

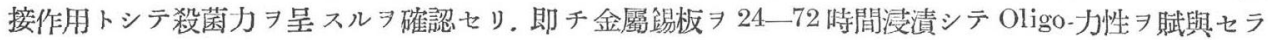
レタル液體ト上記, 菌液ト $724-72$ 時間作用セシメタル二, Oligo-力性賦與時間及菌液卜ノ作用洔間, 多寡ニ因り一樣ナラザルモ, 菌聚落〉減少若シクハ消失习認メタリ。

\section{II. 酒石酸酸化錫-Natrium-複壖及ビ酒石酸-Natrium ノ萳萄 狀球菌傳染二對スル治療作用二就テノ實驗}

\section{a. Maus/菌感染中毒試驗}

余入先ヅ豫備實驗トシテ, 實驗方法二記載スルガ如キ毒性强キ菌 $ヨ$ 用ヒテ, 2 種)菌液ヨ作リ, 其諸

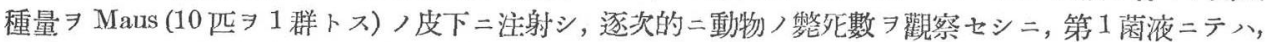
$0,4 \mathrm{ccm}$ 以上投與 >場合二八, 動物 、 24 時閒以内 $=100 \%$, 第 2 菌液二於テハ, $0,3 \mathrm{ccm}=$ テ 24 洔間 以内 $=60 \%, 48$ 時間以內二八 $100 \%$ 擎死七り。

\section{b. 菌感染二及ボス錫複嗑及ビ酒石酸-Natrium /影響}

先ッ゙ 24 時間以内二常 $=100 \%$ /擎死數 ヨ示スガ如キ第 1 菌液 $0,5 \mathrm{ccm}$ ヨ投與シ, 錫 $0,0001-0,001 \mathrm{~g}$

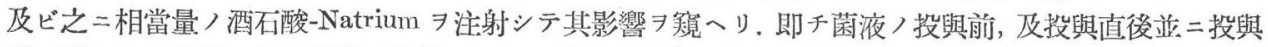

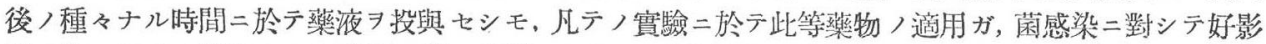

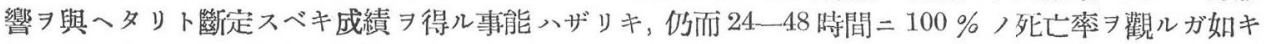

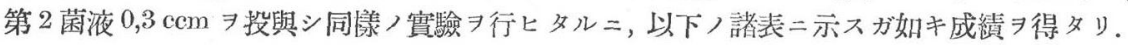

第 2 表. 葡萄牀球菌感染-Maus 二對シ感染後短時間內二藥液投與/場合.

先ヅ菌液 $0,3 \mathrm{ccm}$ ヨ以テ前處置シタル Mals $\ni$, 更二酒石酸々化錫-Natrium-複盐 錫 $0,0005 \mathrm{~g}$ 或ハ之二相賞スル量ノ酒石酸-Natrium 二テ後處置セリ。

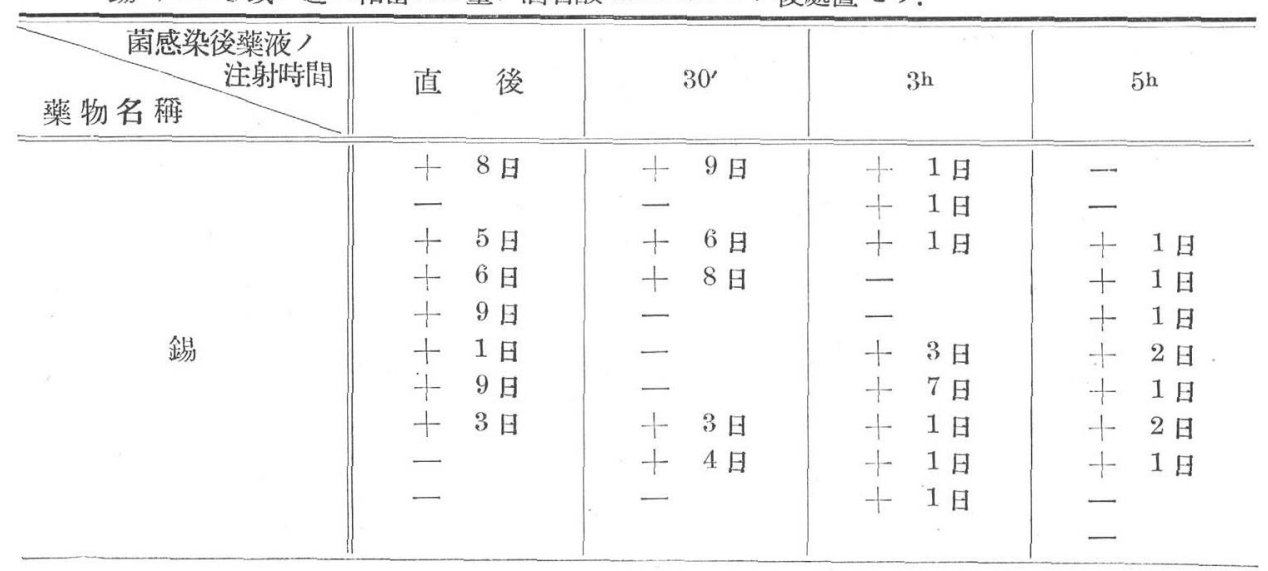




\begin{tabular}{|c|c|c|c|c|}
\hline 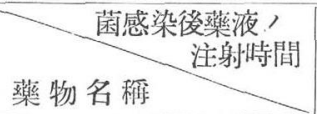 & 直 後 & $30^{\prime}$ & $3 \mathrm{~h}$ & $5 \mathrm{~h}$ \\
\hline 酒石陌夋-Natrinm & $\begin{array}{l}+\quad 9 \text { 日 } \\
+\quad 5 \text { 日 } \\
+\quad 5 \text { 日 } \\
- \\
- \\
+\quad 2 \text { 日 } \\
+\quad 1 \text { 日 } \\
+\quad 9 \text { 日 } \\
-\end{array}$ & $\begin{array}{ll}- & \\
\overline{-} & \\
+ & 3 \text { 日 } \\
+ & 4 \text { 日 } \\
\overline{-} & \\
+ & 1 \text { 日 } \\
+ & 2 \text { 日 } \\
- & \\
- & \\
- & \end{array}$ & $\begin{array}{ll}- & \\
- & \\
+ & 1 \text { 日 } \\
+ & 5 \text { 日 } \\
+ & 1 \text { 日 } \\
+ & 1 \text { 日 } \\
+ & \text { 日 } \\
+ & 1 \text { 日 } \\
- & \\
- & \end{array}$ & $\begin{array}{ll}- & \\
- & \\
+ & 1 \text { 日 } \\
+ & 1 \text { 日 } \\
+ & 1 \text { 日 } \\
- & \\
- & \\
+ & 2 \text { 日 } \\
+ & 2 \text { 日 } \\
+ & 1 \text { 日 }\end{array}$ \\
\hline $\begin{array}{l}\text { 菌＼cjkstart液 } \\
\text { (對，照) }\end{array}$ & $\begin{array}{r}+\quad 1 \text { 日 } \\
+\quad 1 \text { 日 } \\
+\quad 1 \text { 日 } \\
+\quad 1 \text { 日 } \\
+\quad 1 \text { 日 } \\
+\quad 1 \text { 日 } \\
+\quad 1 \text { 日 } \\
+\quad 1 \text { 日 } \\
+\quad 1 \text { 日 } \\
+\quad 1 \text { 日 }\end{array}$ & & & \\
\hline
\end{tabular}

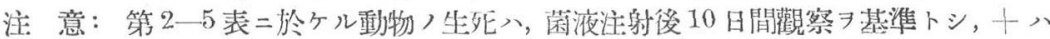
感染整死, 一八耐過生存, 又十二後記七几數字八, 生存日數 ヨ示ス.

第 3 表. 苴液 7 以テ前處置シタル後, 一定侍日 7 經テ菌感染 7 惹起七シメタル場合.

先ヅ酒石酸酸化錫-Natrium-複塭二テ, 錫 $0,00001 \mathrm{~g}$ 或八之

二相當量>酒不酸-Natrium $\exists$ 以テ隔日 3 回前處置シタル

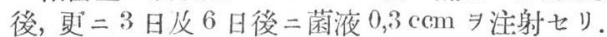

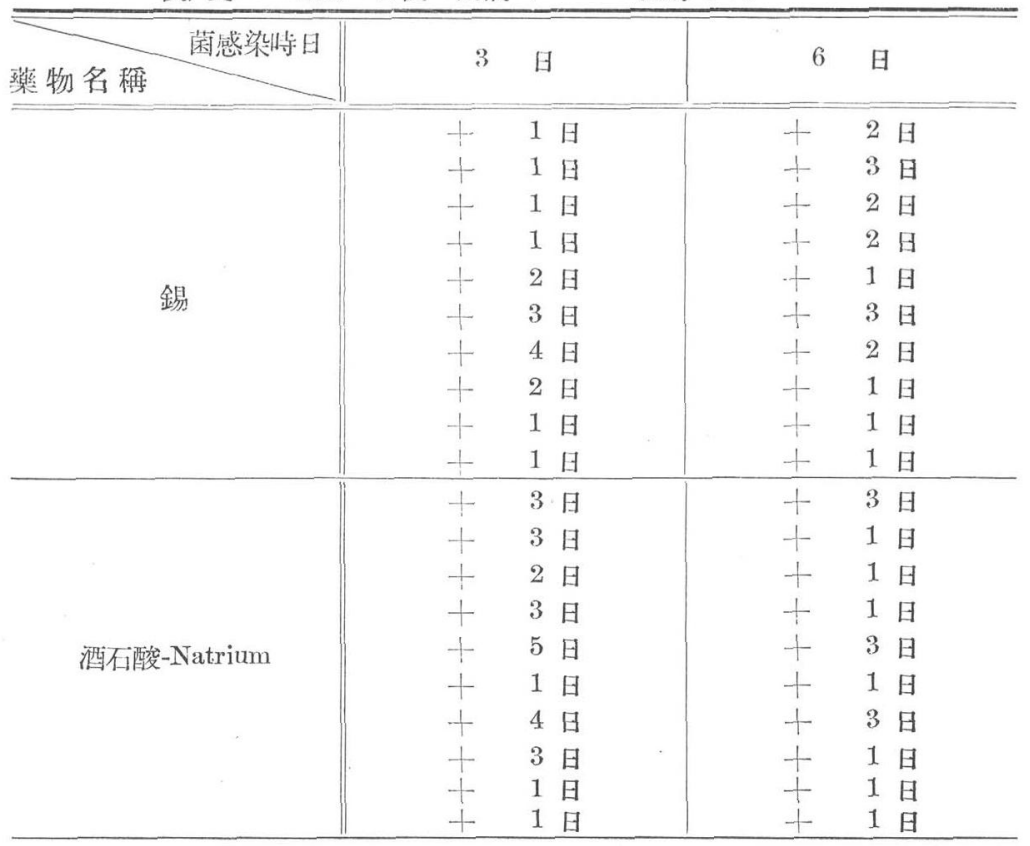




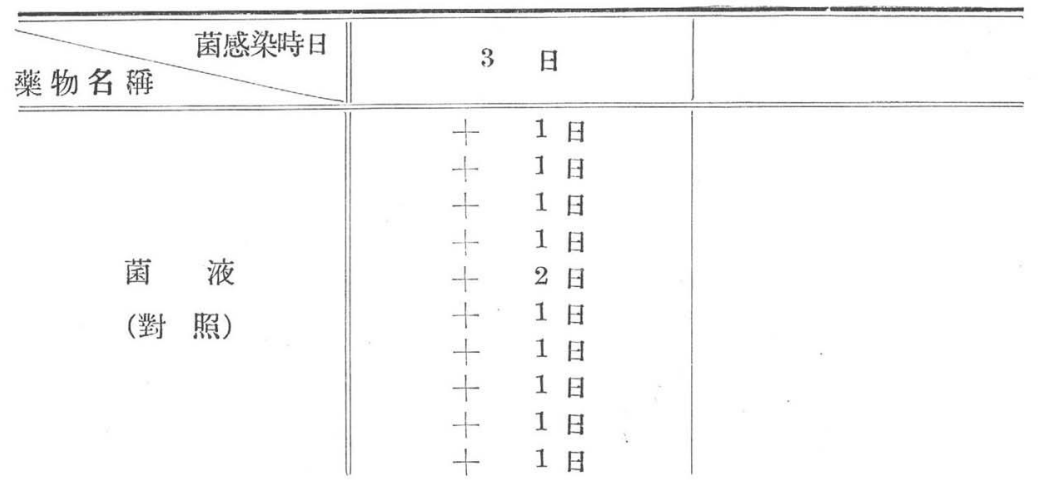

第 4 表. 藥液 7 以テ前處置シタル後, 一定時日 7 經テ菌感染 7 惹起セシメタル場合.

先ヅ酒石酸酸化錫-Natrium-複慮二テ錫 $0,0005 \mathrm{~g}$ 或ハ之二相當量, 酒石酸-Natrium $\ni$ 以テ 前處置シ, 更二 3 日, 7 日, 10 日及ビ 14 日後, 菌液 $0,3 \mathrm{ccm}$ ᄏ注射七り。

\begin{tabular}{|c|c|c|c|c|c|}
\hline 藥物名㩐 菌感染特日 & 3 日 & 7 日 & 10 日 & 14 & 日 \\
\hline 錫 & $\begin{array}{l}+\quad 5 \text { 日 } \\
+\quad 5 \text { 口 } \\
-\quad 9 \text { 日 } \\
+\quad 9 \text { 日 } \\
+\quad 5 \text { 日 } \\
+\quad 7 \text { 日 } \\
+\quad 5 \text { 日 }\end{array}$ & $\begin{array}{l}+\quad 1 \text { 日 } \\
+\quad 1 \text { 日 } \\
+\quad 1 \text { 日 } \\
-\quad \\
- \\
-\quad \\
+\quad 1 \text { 日 } \\
+\quad 2 \text { 日 } \\
+\quad 3 \text { 日 } \\
+\quad 1 \text { 日 }\end{array}$ & $\begin{array}{l}+\quad 1 \text { 日 } \\
+\quad 1 \text { 日 } \\
+\quad 1 日 \\
- \\
- \\
-\quad \\
+\quad 4 \text { 日 } \\
+\quad 2 \text { 日 } \\
+\quad 1 \text { 日 } \\
+\quad 2 \text { 日 }\end{array}$ & $\begin{array}{l}- \\
- \\
- \\
+ \\
+ \\
+ \\
+ \\
+ \\
+ \\
+\end{array}$ & $\begin{array}{l} \\
1 \text { 日 } \\
1 \text { 日 } \\
1 \text { 日 } \\
4 \text { 日 } \\
2 \text { 日 } \\
1 \text { 日 } \\
1 \text { 日 }\end{array}$ \\
\hline 酒石酸-Natrium & $\begin{array}{ll}+ & 5 \text { 日 } \\
- & \\
- & \\
+ & 5 \text { 日 } \\
- & \\
- & \\
+ & 5 \text { 日 } \\
+ & 4 \text { 日 } \\
+ & 5 \text { 日 } \\
+ & 5 \text { 日 }\end{array}$ & 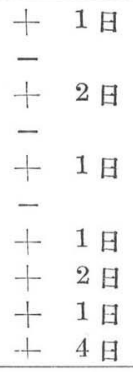 & $\begin{array}{ll}- & \\
- & \\
- & \\
+ & 3 \text { 日 } \\
+ & 3 \text { 日 } \\
+ & 1 \text { 日 } \\
+ & 2 \text { 日 } \\
+ & 5 \text { 日 } \\
+ & 1 \text { 日 } \\
+ & 1 \text { 日 }\end{array}$ & $\begin{array}{l}- \\
- \\
- \\
- \\
+ \\
+ \\
+ \\
+ \\
+ \\
+\end{array}$ & $\begin{array}{l} \\
\\
1 \text { 日 } \\
1 \text { 日 } \\
3 \text { 日 } \\
1 \text { 日 } \\
1 \text { 日 } \\
2 \text { 日 }\end{array}$ \\
\hline $\begin{array}{l}\text { 菌 液 } \\
\text { (對 照) }\end{array}$ & $\begin{array}{l}+\quad 1 \text { 日 } \\
+\quad 1 \text { 日 } \\
+\quad 2 \text { 日 } \\
+\quad 1 \text { 日 } \\
+\quad 1 \text { 日 } \\
+\quad 1 \text { 日 } \\
+\quad 1 \text { 日 } \\
+\quad 1 \text { 日 } \\
+\quad 1 \text { 日 } \\
+\quad 1 \text { 日 }\end{array}$ & & & & \\
\hline
\end{tabular}


第 5 表. 藥液 7 以テ唯 1 回又入隔日 8 回前處置後, 6 日 7 經テ菌感染 7 惹起 セシメタル場合.

先ジ酒石酸酸化錫-Natrium-複罝二テ錫 $0,0005 \mathrm{~g}$ 或八之二匹敵量， 酒石酸-Natrium 7 以テ, 唯 1 回又 $八$ 隔日 3 回前處置シ, 更 $=6$ 日 後菌液 $0,3 \mathrm{ccm} 7$ 注射セリ。

\begin{tabular}{|c|c|c|}
\hline 藥物名程藏感染時日 & 唯 1 回注射 & 隔日 3 回注射 \\
\hline 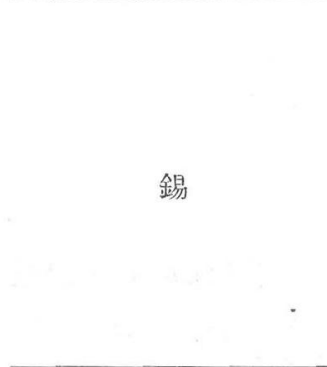 & $\begin{array}{l}+\quad 2 \text { 日 } \\
+\quad 2 \text { 日 } \\
+\quad 2 \text { 日 } \\
-\quad \\
-\quad \\
+\quad 4 \text { 日 } \\
+\quad 2 \text { 日 } \\
+\quad 1 \text { 日 } \\
+\quad 1 \text { 日 } \\
+\quad 2 \text { 日 }\end{array}$ & $\begin{array}{ll}- & \\
- & \\
- & \\
+ & 1 \text { 日 } \\
+ & 5 \text { 日 } \\
+ & 1 \text { 日 } \\
+ & 5 \text { 日 } \\
+ & 1 \text { 日 } \\
+ & 1 \text { 日 } \\
+ & 2 \text { 日 }\end{array}$ \\
\hline 酒不酸-Natrium & $\begin{array}{l}+\quad 3 \text { 日 } \\
+\quad 3 \text { 日 } \\
+\quad 2 \text { 日 } \\
+\quad 1 日 \\
+\quad 1 日 \\
+\quad 1 日 \\
+\quad 2 \text { 日 } \\
+\quad 1 日 \\
+\quad 2 \text { 日 } \\
-\quad\end{array}$ & $\begin{array}{l}+\quad 1 \text { 日 } \\
+\quad 5 \text { 日 } \\
+\quad 5 \text { 日 } \\
+\quad 1 \text { 日 } \\
-\quad \\
+\quad 2 \text { 日 } \\
+\quad 2 \text { 日 } \\
+\quad 5 \text { 日 } \\
+\quad 2 \text { 日 } \\
+\quad 1 日\end{array}$ \\
\hline $\begin{array}{l}\text { 菌 液 } \\
\text { (對 照) }\end{array}$ & $\begin{array}{r}+\quad 1 \text { 日 } \\
+\quad 1 日 \\
+\quad 1 日 \\
+\quad 1 日 \\
+\quad 1 日 \\
+\quad 1 日 \\
+\quad 1 日 \\
+\quad 1 日 \\
+\quad 2 \text { 日 } \\
+\quad 1 日\end{array}$ & \\
\hline
\end{tabular}

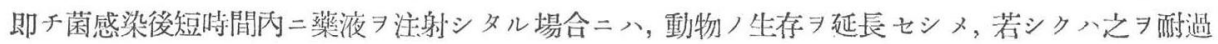
セシメタルモ>ト認ム(第 2 表參照)。文錫 $0,00001-0,0005 \mathrm{~g} 7$ 以テ隔日 3 回處置後, 一定峙日 7 經テ菌 感染习行ヒタル二, 錫 $0,00001 \mathrm{~g}$ ヨ注射シタル場合二八, 㱠ド效果习觀ル能ハザリシモ(第3 表參照),

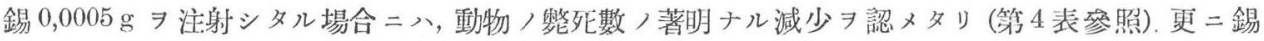
$0,0005 \mathrm{~g} \Rightarrow$ 以テ唯 1 [回前處置シタルモノト隔日 3 回處置シタルモノ , 最後 / 注射後一定侍日 7 經テ菌

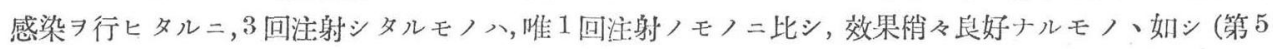
表參照). 埛酒石酸-Natrium /場合モ亦, 上記錫/場合卜大差ナキモノト認么.

上記實驗諸成績 7 觀ルニ, 一定, 量的範圍二於テ少量, 錫子菌感染動物, 皮下二注射 スル時, 及ビ數回少量つ錫フ以ラ處置シタル動物二菌フ投與シタル場合二八, 動物ハ菌感 染二對シ, 一定, 而過力 獲得スルモ, 、如シ。而シラ酒石酸-Natrium ニョリテモ亦, 上 
記ト殆ド同樣ノ成績ヌ得タリ。按之, 錫複䁪及ビ酒石酸-Natriumハ何レモ菌體二對シテハ 直接殺菌性キ有セザルモ, 此等藥物, 生體內注射後, 動物生體ハ一定ノ抗菌性テ賦興七ラ レタルモノト想像セラル、即手少量, 錫フ唯 1 回注射シタル後, 一定時閒經過入ルトキハ, 既二抗毒性乃至抗菌性尹認ムルモ, 佾數回二瓦り錫自身ニヨル中毒顯著ナラザル量的範園 二於テ錫丹投與セル場合二八, 菌二對スル抵抗力八相當保持セラル、モ)、如シ. 仍而余 八上記, 作用ガ前篇二述ベタルガ如半網狀織內皮細胞系統二對スル錫複盍, 刺战興奮作用 ト一定, 關係下ニアルヤ否ヤ

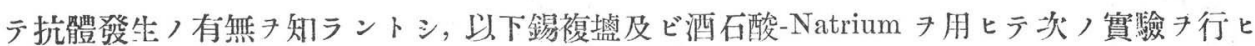
タリ.

\section{Opsonin-係數ノ測定並二菌凝集反應試驗}

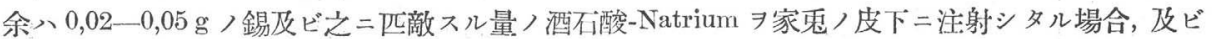
諸種量, Vaccin 7 注射シタル㷋, 藥液 7 與へタル場合, 並二藥液 7 以テ前處置シタル後, Vaccin 7 投 與シタル場合等二於ケル Opsonin-係數及ビ凝集價 其一定量二於テ, Opsonin-係數入不規則ナルモ, 藥物注入後3-5 日二テ增加シ始メ, 10 日万至 2 週間特

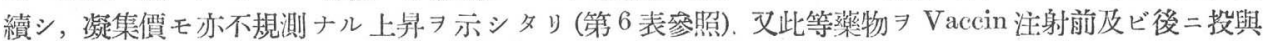
シタル場合モ亦，上記成績卜大同小翼ナリ (第 7 表參照). 倫藥物 7 多量 $=$ 注射スルモ用量二比シ， ヨリ 大ナル效果习認メザリキ。

第6 表 A. Opsonin-係數 测定並二菌凝集反隹試驗成嘖

酒石酸酸化錫-Natrium 複點 (錫: $0,03 \mathrm{~g}$ ) 7 以テ處置シタル場合.

家秃 Nr. 60。體重： $2,565 \mathrm{~kg} \hat{\text { o. }}$

\begin{tabular}{c||c|c|c}
\hline \hline 實驗日 & 平均哴菌數 & Opsonin-係數 & 凝 集 價 \\
\hline \hline $13 / \mathrm{X}$ & 2,72 & 1,00 & 50 \\
$15 / "$ & 2,94 & 1,08 & 50 \\
$\rightarrow 17 / "$ & 2,46 & 1,91 & 100 \\
$20 / "$ & 3,44 & 1,27 & 100 \\
$23 / "$ & 6,08 & 2,25 & 200 \\
$26 / "$ & 5,09 & 1,88 & 400 \\
$29 / "$ & 4,22 & 1,56 & 200 \\
$1 / \mathrm{XI}$ & 5,42 & 2,00 & 200
\end{tabular}

家鬼 Nr.61. 體重: $2,605 \mathrm{~kg}$ 令。

\begin{tabular}{|c|c|c|c|}
\hline 實驗日 & 平坛喰茼數 & Opsonin-係數 & 凝集價 \\
\hline $13 / X$ & 2,66 & 0,90 & 100 \\
\hline $15 / "$ & 3,62 & 1,23 & 50 \\
\hline$\rightarrow 17 / "$ & 2,52 & 0,86 & 100 \\
\hline $20 / "$ & 4,90 & 1,67 & 50 \\
\hline $23 / "$ & 5,10 & 1,76 & 200 \\
\hline $26 / "$ & 3,99 & 1,36 & 400 \\
\hline $29 / "$ & 5,00 & 1,70 & 200 \\
\hline $1 / X$ & 3,86 & 1,31 & 100 \\
\hline
\end{tabular}

注意：第 $6-7$ 表二於テ $\rightarrow$ 藥液注射日, $\rightarrow$ 八菌液注射日 7 示ス.

第 7 表 B. Opsonin-係數ノ測定並二菌凝集反倠試驗成績.

酒不酸酸化錫-Natrium-複䀣中二含有スル錫 $0,03 \mathrm{~g}=$ 相當スル酒石酸-Natrium 7 以テ處置シタル場合.

家鬼 Nr. 70. 體重: $2,680 \mathrm{~kg}$ 。̂.

\begin{tabular}{c||c|c|r}
\hline \hline 實驗日 & 平坛喰菌數 & Opsonin-係數 & 凝 集 價 \\
\hline \hline $13 / X$ & 3,22 & 0,96 & 50 \\
$15 / "$ & 3,58 & 1,07 & 100 \\
$\rightarrow 17 / "$ & 3,21 & 0,96 & 50 \\
$20 / "$ & 4,08 & 1,22 & 100 \\
$23 / "$ & 4,00 & 1,20 & 400 \\
$26 / "$ & 3,68 & 1,10 & 200 \\
$29 / "$ & 4,82 & 1,74 & 200 \\
$1 / X I$ & 5,00 & 1,50 & 100
\end{tabular}

家躳 Nr. 71. 體重: $2,250 \mathrm{~kg}$ ○。

\begin{tabular}{c||c|c|c}
\hline \hline 實驗日 & 平均喰菌數 & Opsonin-係數 & 凝 集 價 \\
\hline \hline $13 / X$ & 3,35 & 0,49 & 50 \\
$15 / "$ & 3,51 & 1,03 & 50 \\
$\rightarrow 17 / "$ & 3,29 & 0,97 & 100 \\
$20 / ”$ & 3,20 & 0,94 & 100 \\
$23 / "$ & 3,70 & 1,09 & 200 \\
$26 / "$ & 4,00 & 1,18 & 200 \\
$29 / ”$ & 3,96 & 1,17 & 100 \\
$1 /$ XI & 4,08 & 1,20 & 100 \\
\end{tabular}


第 7 表. A. Opsonin-係數, 測定並二菌凝集反應試驗成嘖. Vaccin $0,75 \mathrm{ccm}$ 以广前處置シタル家鬼 7 , 更二酒石酸酸化錫-Natrium複塩( 錫: $0,03 \mathrm{~g}$ ) 二テ後處置シタル場合.

家鬼 Nr. 37, 體重： $2,328 \mathrm{~kg}$ ô.

\begin{tabular}{c||c|c|c}
\hline \hline 實驗日 & 平均飡菌數 & Opsonin-係數 & 凝 集 價 \\
\hline \hline $18 /$ IX & 3,69 & 1,12 & 100 \\
$20 / ”$ & 2,96 & 0,90 & 50 \\
$22 / ”$ & 3,21 & 0,97 & 50 \\
$\rightarrow 24 / ”$ & & & \\
$\rightarrow 25 / "$ & & & \\
$27 / "$ & 3,92 & 1,19 & 400 \\
$30 / "$ & 6,02 & 1,82 & 1600 \\
$3 / \mathrm{X}$ & 4,98 & 1,51 & 800 \\
$6 / "$ & 4,51 & 1,37 & 400 \\
$9 / "$ & 5,66 & 1,73 & 400 \\
$12 / "$ & 4,98 & 1,52 & 200
\end{tabular}

家鬼 Nr. 38. 體重： $2,259 \mathrm{~kg}$ 交.

\begin{tabular}{c||c|c|r}
\hline \hline 實驗日 & 平圷喰菌數 & Opsonin-係數 & 凝 集 價 \\
\hline \hline $18 / 1 X$ & 3,25 & 1,03 & 100 \\
$20 / ”$ & 2,95 & 0,96 & 50 \\
$22 / ”$ & 3,24 & 1,02 & 100 \\
$\rightarrow 24 / ”$ & & & \\
$\rightarrow 25 / ”$ & & & \\
$27 / "$ & 3,17 & 1,00 & 400 \\
$30 / ”$ & 4,00 & 1,26 & 800 \\
$3 / X$ & 3,91 & 1,24 & 1600 \\
$6 / ”$ & 3,70 & 1,17 & 400 \\
$9 / ”$ & 4,19 & 1,33 & 200 \\
$12 / ”$ & 3,89 & 1,23 & 400 \\
& & &
\end{tabular}

第 7 共. B. Opsonin-係數, 測定並二菌凝集反雄試驗成績.

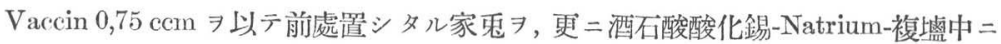
含有スル錫 $0,03 \mathrm{~g}=$ 相當量ノ酒不酸-Natrium 二テ後處置シタル場合.

家乐 Nr. 40. 體重：2,185 kg 古。

\begin{tabular}{|c|c|c|c|}
\hline 實驗日 & 平坛喰菌嘍 & Opsonin-係數 & 凝集㬐 \\
\hline $18 / I X$ & 3,76 & 1,11 & 50 \\
\hline $20 / "$ & 3,06 & 0,90 & 50 \\
\hline $22 / "$ & 3,35 & 0,98 & 100 \\
\hline$\rightarrow 24 / \Rightarrow$ & & & \\
\hline$\rightarrow 25 / \|$ & & & \\
\hline $27 / "$ & 2,98 & 0,87 & 400 \\
\hline $30 / "$ & 5,92 & 1,74 & 1600 \\
\hline $3 / X$ & 4,86 & 1,43 & 800 \\
\hline $6 / "$ & 5,02 & 1,48 & 400 \\
\hline $9 / "$ & 3,72 & 1,10 & 100 \\
\hline $12 / "$ & 4,42 & 1,30 & 50 \\
\hline
\end{tabular}

家鬼 Nr. 41. 體重： $2,355 \mathrm{~kg}$

个.

\begin{tabular}{|c|c|c|c|}
\hline \multirow{2}{*}{$\begin{array}{c}\text { 實驗日 } \\
18 / 1 X\end{array}$} & \multicolumn{2}{|c|}{ 平均喰菌數 Opsonin-係數 } & \multirow{2}{*}{$\begin{array}{c}\text { 凝集 價 } \\
100\end{array}$} \\
\hline & 3,29 & 1,05 & \\
\hline $20 / "$ & 3,00 & 0,95 & 50 \\
\hline $22 / "$ & 3,07 & $\mathbf{0 , 9 8}$ & 50 \\
\hline$\rightarrow 24 / "$ & & & \\
\hline$\rightarrow 25 / "$ & & & \\
\hline $27 / "$ & 3,00 & 0,95 & 800 \\
\hline $30 / "$ & 4,09 & 1,30 & 1600 \\
\hline $3 / \mathrm{X}$ & 3,92 & 1,35 & 800 \\
\hline $6 / "$ & 4,00 & 1,27 & 400 \\
\hline $9 / "$ & 3,27 & 1,04 & 100 \\
\hline $12 / "$ & 3,91 & 1,24 & 200 \\
\hline
\end{tabular}

上記諸成績 總括スルニ, 金屬錫, Oligo-刀性液八諸種, 葡萄狀球菌二對シテ. 其發育

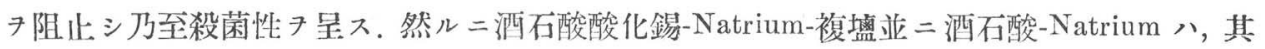
濃厚ナル溶液子使用スルモ, 菌發青阻止乃至殺菌作用丹全ク呈セズ、然レ共锡複血及ビ酒 石酸-Natrium 7 生體內二投與スル時八, 蒱芻狀球菌傳染-Maus 生存日數子延長乃至傳染 二耐過セシム. 刃藥液子 3 回二互りラ動物二注射スルトキハ，一定封日間同樣ノ抗傳染性 作用丹獲得スルモ>、如シ. 而シテ本作用八酒石酸-Natrium ニョリテモ, 殆ド同樣二發現

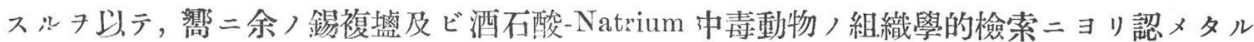
網壯織内皮細胞系統, 刺战作用ト一定, 關係下二アルモ, 、如ク，又更二家兔二於テ適當

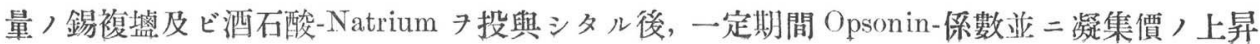


タ認メタル事實ヨリ觀ルモ, 該抗傅染性作用ガ, 此等塭類, 網狀織內皮細胞系統二對スル 特殊作用卜密接ナル關係下ニアルタ想起七シム。但シ此際踢自己ガ上記, 特殊作用二對シ

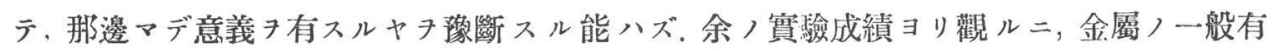

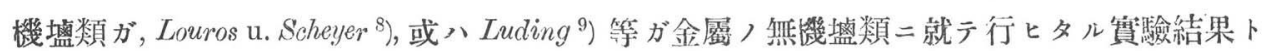
同樣ノ性質キ有スルモノナルキ推測セシム。

\section{結論}

1. Maus 二對シテハ, 酒石酸酸化錫-Natrium-複塩キ通ジテ䂓ヒタル錫ノ急性作用トシ テハ, 結局呼吸障碍，運動障碍等ノ中樞的症狀ヌ現ハスモ，著明ナルモノ二非ズ，而モ同樣 ，作用八（對照タル）酒石酸-Natrium，作用下二モ現ハレ，唯前者ガ量的二稍々强カナル 作用э旺スルノミ。

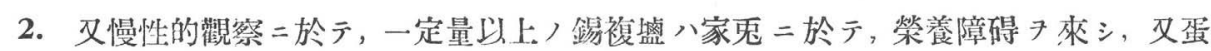
白尿丹招來ス。同㨾ノ作用八結局酒石酸-Natrium ニョリテモ惹起七ラル、モ，其度輕度 ナリ.

3. 本複塭及ビ對照タル酒石酸-Natrium キ以テ中毒セシメタル試獸) 剖驗所見二於テ, 兩者其程度 7 異ニスレ共, 脾 旰及ビ腎, 充血, 特二大腸起始部, 著色變化 7 認メ, 又其組織

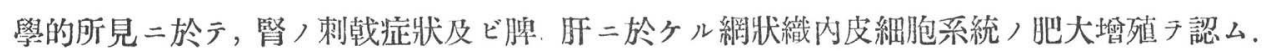

4. 錫, Oligo-力性溶液八蒱萄狀球菌二對シテ直挼發育阻此乃至殺菌作用 酒石酸々化錫-Natrium-複壏及ビ酒石酸-Natrium 二於テハ如斯作用全クナシ.

5. 酒石酸酸化錫-Natrium-複漗及ビ酒石酸-Natrium 八, 共二其一定量 $=ヨ リ$, 蒱葡狀 球菌傳染二對シテ對抗スルモ, 、如シ. 又其一定量 $又$ 反覆注射シタル場合二八, 最後, 沣 射後, 一定期間抗傳染性作用丹呈スルモ,ト認ム。

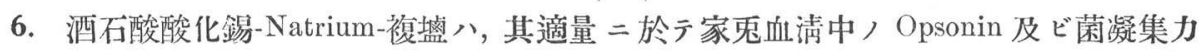
增加スル作用アリ。

7. 如上記, 作用八錫複盐二匹敵スル量, 酒石酸-Natrium ニョリテモ亦殆ド同樣二發 現ス。

本研究二於テ, 病理組織學的檢索二際シテ八, 黑岩助呚授ヨリ, 又微生物學的檢索二對シテハ, 特二

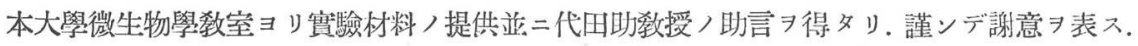

\section{引用書 目}

1) Husemann: Handb. d. Toxikologie 862 (1862).

8) Orfïla: Lehrb. d. Toxikologie 2, 1 (1853).

3) White: Arch. f. exp. Pathol u. Pharmakol. 13, 53 (1881).

4) Handovslyy: Ibid 114, 39 (1926). 
5) Schübel: Heffters Handb d. exp. Pharmakol. 3, 1561 (1934).

6) Lehmann: Arch f. Hyg. 45, 108 (1902).

7) Ungar u. Bodländer: Zeitschr. f. Hyg. 2, 241 (1887).

8) Louros u. Scheyer: Zeitschr. f. d. gesamt. exp. Med. 57, 221 (1927).

9) Heinrich Luding: Ibid. 71, 554 (1930).

10) Jaksch: Nothnagel, specielle Pathologie n. Therapie I B, Die Vergiftungen 164, 242 (1910).

11) Madsen u. Salomonsen: Zit. n. Walbum u. Schmidt, Zeitschr. f. Imm. forschg. 43, 32 (1925).

12) Walbum: Keitschr. f. Imm. forschg. 47, 555 (1926).

13) Derselbe: Ebenda 47, 2131 (1926).

14) Derselbe: Ebenda 49, 538 (1927).

15) Louros u. 8chmeckel: Zeitschr. f. d. gesamt. exp. Med. 57, 440 (1927).

16) Kionka: Grundriss d. Toxikologie 168 (1901).

17) Elsexcelri: Pathologische Anatomie u. Histologie d. Vergiftungen (1930).

18) Gadamel: Lehrb. d. chemische Toxikologie 201 (1909).

19) Lewin: Gifte u. Vergiftungen 4. Aufl. 221, 222 и. 311 (1929).

20) Kobert: Lehrb. d. Intoxikation 2. Aufl. 388 (1906).

21) Schwartze u. Clark: Journ. of Pharmacol. 31, 224 (1927)

22) Kwokel: Handb. d. Toxikologie 214 (1901).

23) Rico, J. T'ossano: Compt. rend. Soc. Biol. Paris 90, 1098 (1924).

24) 錦織：京都醫學雜誌 45, 245 (昭和 5 年).

25) 石井：日本微生物學病埋學雜誌 22, 2425-2472 (昭和 3 年).

26) Etainoxyl 文献炛 圓战商會二據儿。

27) 松林：北越㡠學會雜誌 45,245 (昭和 5 年).

28) Frouin et Greggoire：Etainoxyl 文献集蹟城商會二據儿。

29) 矢部：同上. 